\title{
Mortarless Interlocking Hollow Blocks: An Innovation
}

\author{
Francia H. Tomenio ${ }^{1}$, Elias L. Tomenio ${ }^{2}$ \\ ${ }^{1,2}$ College of Engineering, Camarines Sur Polytechnic Colleges, Philippines \\ ${ }^{1}$ franciahtomenio@cspc.edu.ph, ${ }^{2}$ eliastomenio@ cspc.edu.ph
}

\begin{abstract}
This paper presents the design of mortarless interlocking hollow blocks for non-load bearing walls. The compressive strength was determined and compared to the ASTM and PTSS standards for CHB. The cost of construction was also determined. There are three designs of the mortarless interlocking hollow blocks, the straight block with a dimension of $45 \mathrm{~cm} \times 10 \mathrm{~cm} \times 20 \mathrm{~cm}$ with a hollow dimension of $7.5 \mathrm{~cm} \times 5 \mathrm{~cm} \times 18.1 \mathrm{~cm}$, the corner block has a dimension of $10 \mathrm{~cm} \times 10 \mathrm{~cm} \times 20 \mathrm{~cm}$, and the 1-shaped block with a dimension of $30 \mathrm{~cm} \times 10 \mathrm{~cm} \times 20 \mathrm{~cm}$ with a hollow dimension of $7.5 \mathrm{~cm} \times 5 \mathrm{~cm} \times 18.1 \mathrm{~cm}$, the radius of the tongue and groove is $3 \mathrm{~cm}$. Using t-test, the compressive strength of the MIHB was found to be greater than the ASTM standards and PTSS standards. The cost for installation and plastering of the commonly used $\mathrm{CHB}$ is higher than the cost for laying-out the mortarless interlocking hollow blocks.
\end{abstract}

Key words: Compressive strength, hollow blocks, interlocking, mortarless

\section{INTRODUCTION}

One of the most established and biggest industries worldwide is the construction industry. There is an extensive range of construction procedures, modern designs, and materials that serves the various needs of the industry and society. It also uses innovative methods and techniques to develop or improve construction materials that would be economical, durable, and acceptable for use.

The Concrete Hollow Blocks, popularly known as CHB is one of the basic components in the construction industry. This is also one of the most widely used walling materials in the Philippines. CHB is used in all types of buildings and it can be utilized for all types of walls. It is maybe rectangular or segmented and may have end shape to provide interlock at joints. The standard hollow block has three void cells ranges from 4-6 inches thick.

Significant studies and researches on masonry units had been made either in strength or in design. To estimate the compressive strength of concrete hollow block masonry prisms, the use of artificial neural networks and adaptive neuro-fuzzy inference systems have been utilized. It was found out that with a very minimal percentage of error, the proposed models have outstanding prediction capability.[1]

An experimental study was done to determine the effects on the compressive strength of using mortar for the block system. From the results of the experiment, the empirical formula in determining the compressive strength of the masonry system was derived.[2]

There is also a study on the utilization of bottom ash as a substitute for sand for mortar in 5\%,10\%, 15\%, 20\%, and $25 \%$ ratio. The workability of the fresh mortar mix and the compressive strength of the samples were determined and the specimen with $15 \%$ sand replacement was the best proportion.[3] Portland cement was replaced by corncob ash in different ratios of 5, 10, and $15 \%$. The water adsorption capacity, unit weight, and the compressive strength of the interlocking blocks were compared with the Nigerian standard specifications. Further, the cost of production and the physical characteristics of the blocks using corncob ash were compared to the conventional hollow blocks using cement and sand.[4]

To analyze the influence of the geometric shapes on the compressive strength and capacity of concrete hollow blocks, H-shaped and cross-shaped hollow blocks were developed. It was the core horizontal rib of the H-shaped series which played a significant role in coming up with a higher compressive strength capacity. The core horizontal ribs and joints adjacent to them showed early damage for cross-shaped ribs. For both shapes, the improvement of the vertical rib and concrete strength can efficiently increase the strength of the blocks. [5]

Using interlocking mortarless hollow blocks, an experiment was done on five (5) masonry wall panels. The walls were then subjected to compressive vertical and lateral loading. Results showed that there is an increase in lateral load wall capacity for a corresponding increase in the compressive load. There was a wall failure because of diagonal shear and crushing at the toe of the wall which is proportional to the magnitude of the load.[6]

As a substitute to the conventional bonded blocks, an interlocking block system termed as "PUTRA BLOCK" was also developed for load-bearing wall construction. The density, areas for bearing and shear, geometric shapes, interlocking efficiency, and production methods of samples 
were determined and analyzed. The blocks were efficiently utilized in the construction of a single-story residential building.[7] The continuous increase in the cost of construction materials is a big challenge to find alternatives to lower the construction cost. Universiti Teknologi Malaysia in collaboration with an industry partner has developed a building system using interlocking blocks. The system produced cheaper building costs, less-skilled laborers ad fewer wastages.[8]

The interlocking mechanism of the interlocking-block masonry system is significant in increasing the ratio of the concentric to the eccentric load capacity of the block system as compared with the traditional masonry system. Further, the flexural capacity perpendicular to the plane is higher compared with the capacity parallel to the plane.[9] There had been a lot of studies and experiments on the different types of interlocking mortarless masonry blocks but there is still a little understanding of the behavior of the joints on the action of compressive loads and their effect on the whole system. An experimental study was done to investigate the behavior of the joint both for grouted and ungrouted block system. Differences in the compressive strength and deformations in grouted samples are reduced compared with the ungrouted samples.[10]

A study recommended a standard to evaluate and classify the shapes of concrete hollow blocks by adopting a simple graph.[11] New trends in the construction to come up with a reasonable and earthquake-resilient structure is a must nowadays. Interlocking blocks using coconut fibers were fabricated for easy and faster wall construction. Results showed that the compressive strength of the bottom blocks is higher than the other blocks. Also, individual blocks have higher compressive capacity compared with multiple blocks.[12] The interlocking mortarless block system is truly advantageous in terms of weight, strength, cost, and duration of construction.[13] Because of its advantages, the local communities have opted to utilize them in construction.[14]

With the above-cited developments on interlocking concrete hollow blocks, the researchers were inspired to create a new design of interlocking mortarless concrete hollow blocks that would be of high quality, affordable and would lessen the use of mortar during construction. This could be used for the construction of low-cost residential buildings specifically in the Philippines. The compressive strength of the mortarless interlocking hollow blocks was determined and compared with the ASTM (American Society for Testing Materials) Standards and PTSS (Philippine Trade Standards Specifications) for CHB. Also, the advantages of the mortarless interlocking hollow blocks in terms of cost were considered.

\section{MATERIALS AND METHODS}

This research used descriptive and experimental methods of research to undertake this particular study. Thru experimentation, the compressive strength of the mortarless interlocking hollow block was determined.

\subsection{Statistical Treatment}

The researchers used a t-test to determine the significant difference in the compressive strength of the blocks with the ASTM (American Society for Testing Materials) and PTSS (Philippine Trade and Standards Specification).

\subsection{Materials/Equipment}

The researchers utilized various tools and equipment in the study. This includes weighing scale, concrete mixing tools, and CHB mold. Universal Testing Machine (UTM) was used to determine the performance of MIHB in terms of compressive strength.

\subsection{Research Procedure}

The following procedures were done to undertake this study

a. Design of Molds. The mold of the mortarless interlocking hollow blocks was fabricated using the commonly used mold for ordinary concrete hollow blocks. Three molds were fabricated. These are for straight blocks, corner blocks, and L-shaped blocks. Shown in the figure below are the molds used in this study.

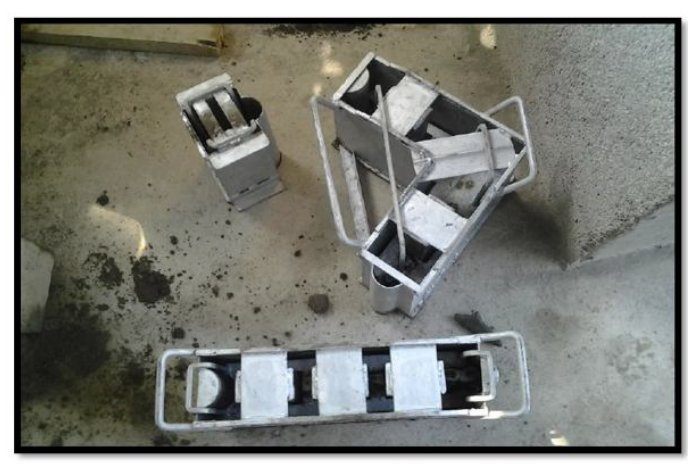

Figure 1: Molds for the mortarless interlocking hollow blocks

Figure 1 shows the molds used for the mortarless interlocking hollow blocks.

b. Preparation of Materials. The researchers selected and obtained a sample of materials such as cement, fine aggregates, and water.

Cement. The Portland cement Type 1 is commonly used in general construction works such as bridges, roads, and reinforced concrete buildings. This type of cement was used in the mixture.

Fine Aggregates. Fine aggregates were carefully examined to ensure that it is free from organic impurities that may affect the settling of the cement paste, to obtain hard durable and clean materials. 
Water. The researchers used the water from Nabua Water District in the mixture of the Mortarless Interlocking Hollow Blocks.

\section{c. The casting of Mortarless Concrete Hollow Block with the Design mixture.}

The design mixture used for the standard local concrete hollow blocks was adopted in casting MIHB. Three ratios for the cement to sand were used and these are 1:10,1:8, and 1:7. Three samples for each mixture were casted.

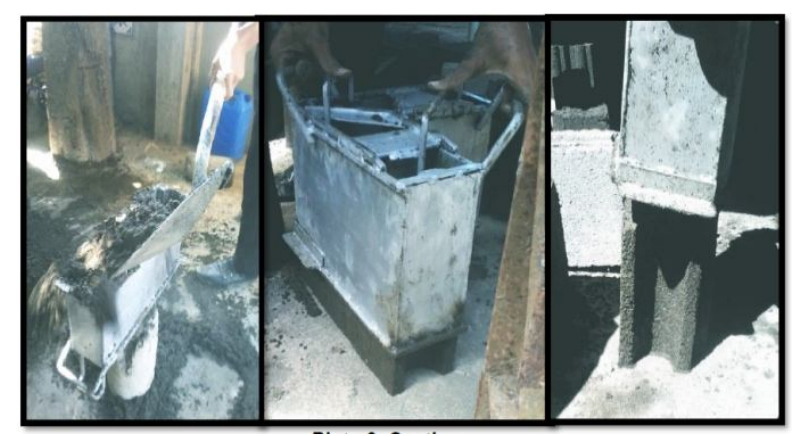

Figure 2: The casting of the mortarless interlocking hollow blocks

Figure 2 shows the actual casting of the mortarless interlocking hollow blocks.

\section{d. Curing of the Samples}

The samples were cured for 14 days. Curing was done by sprinkling the samples with water daily to maintain the moisture.

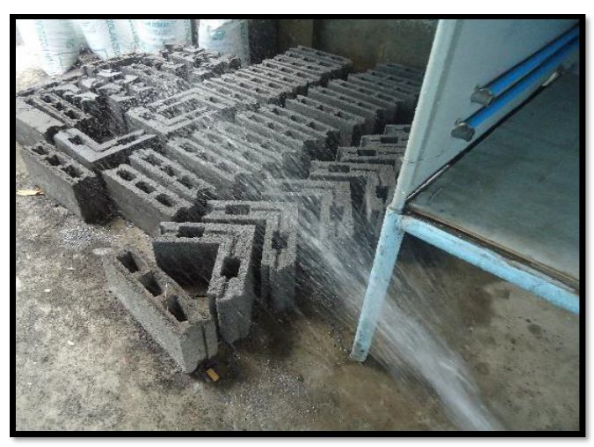

Figure 3: Curing of the mortarless interlocking hollow blocks

Figure 3 shows the curing of the mortarless interlocking hollow blocks.

\section{e. Testing of Mortarless Interlocking Hollow Block.}

The samples were subjected to a compressive strength test using the Universal Testing Machine. The figure below shows the actual testing of the MIHB.

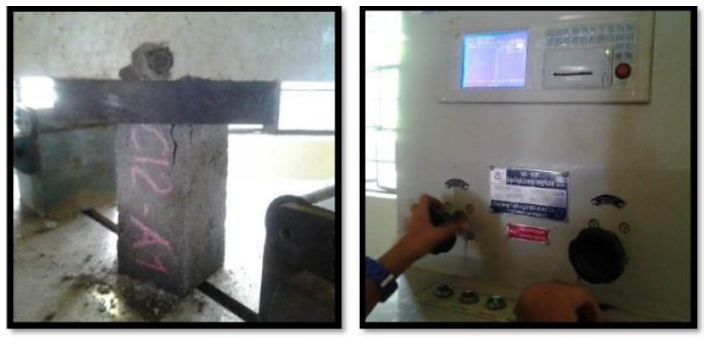

Figure 4: Testing of the mortarless interlocking hollow blocks

\section{RESULTS AND DISCUSSION}

\subsection{Design of Mortarless Interlocking Hollow Blocks}

Table 1: Dimensions of the Mortarless Interlocking Hollow Blocks

\begin{tabular}{|c|c|c|c|c|c|c|c|}
\hline \multirow[b]{2}{*}{ Design } & \multicolumn{3}{|c|}{ Block Dimension } & \multirow{2}{*}{$\begin{array}{c}\text { Radius } \\
\text { of } \\
\text { Tongue } \\
\text { and } \\
\text { Groove } \\
\text { (cm) }\end{array}$} & \multicolumn{3}{|c|}{ Hollow Dimensions } \\
\hline & $\underset{\mathbf{c m}}{\mathbf{L}}$ & $\begin{array}{l}W \\
\mathbf{c m}\end{array}$ & $\begin{array}{c}\mathbf{H} \\
\mathbf{c m}\end{array}$ & & $\underset{(\mathbf{c m})}{\mathbf{L}}$ & $\underset{(\mathbf{c m})}{\mathbf{W}}$ & $\underset{(\mathbf{c m})}{\mathbf{H}}$ \\
\hline Straight Block & 40 & 10 & 20 & 3 & 7.5 & 5 & 18.1 \\
\hline Corner Block & 10 & 10 & 20 & 3 & & & \\
\hline L-Shaped Block & 30 & 10 & 20 & 3 & 7.5 & 5 & 18.1 \\
\hline
\end{tabular}

Table 1 shows the dimensions of the Mortarless Interlocking Hollow Blocks. There are three designs, the straight block with a dimension of $40 \mathrm{~cm} \times 10 \mathrm{~cm} \times 20 \mathrm{~cm}$ with a hollow dimension of $7.5 \mathrm{~cm} \times 5 \mathrm{~cm} \times 18.1 \mathrm{~cm}$, the corner block has a dimension of $10 \mathrm{~cm} \times 10 \mathrm{~cm} \times 20 \mathrm{~cm}$, and the L-shaped block with a dimension of $30 \mathrm{~cm} \times 10 \mathrm{~cm} \times 20 \mathrm{~cm}$ with a hollow dimension of $7.5 \mathrm{~cm} \times 5 \mathrm{~cm} \times 18.1 \mathrm{~cm}$, The radius of the tongue and groove is $3 \mathrm{~cm}$.
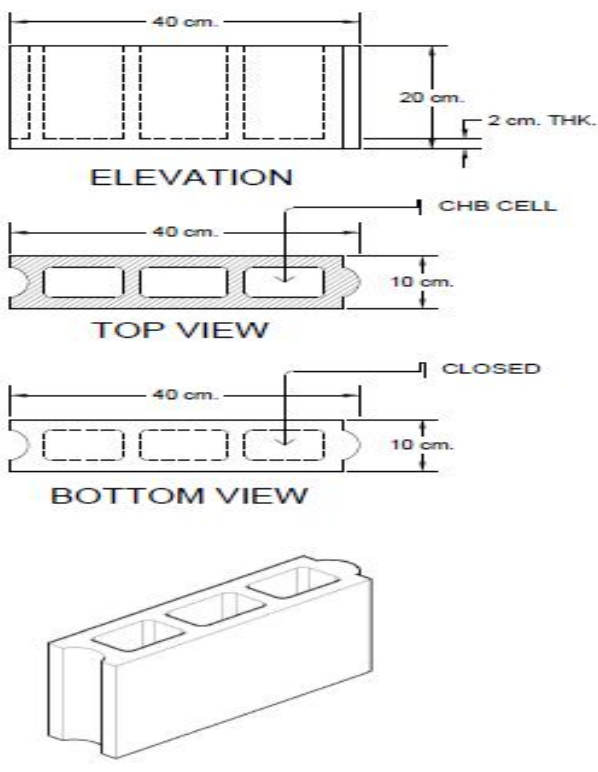

ISOMETRIC VIEW

Figure 5. Technical views of the mortarless interlocking blocks (straight block) 
Francia H. Tomenio et al., International Journal of Emerging Trends in Engineering Research, 8(7), July 2020, 3804- 3810

Figure 5 shows the top, bottom, and isometric view of the straight mortarless interlocking block.
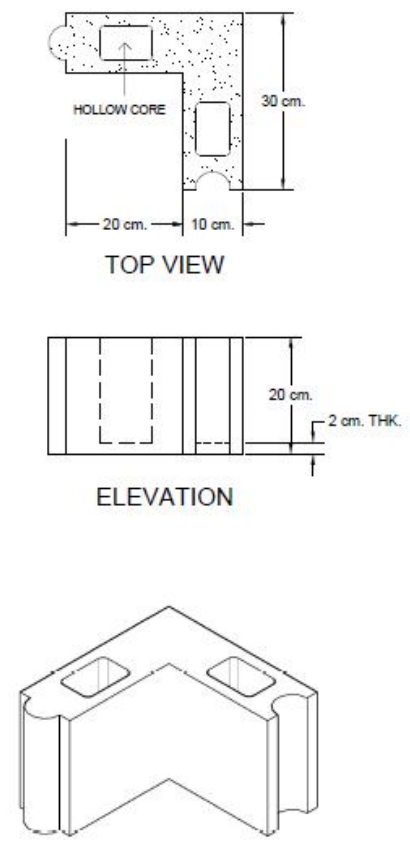

ISOMETRIC VIEW

Figure 6: Technical views of the mortarless interlocking blocks (L-shaped block)

Figure 6 shows the top, bottom, and isometric view of the L-shaped mortarless interlocking block.

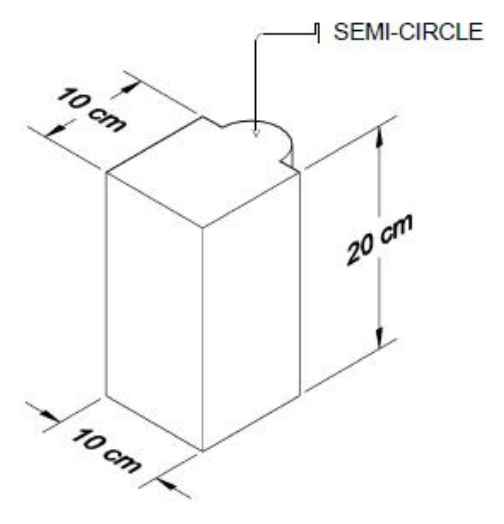

ISOMETRIC VIEW

Figure 7: Isometric view of the mortarless interlocking blocks (corner block)
Figure 7 shows the top, bottom, and isometric view of the corner mortarless interlocking block.

\subsection{Compressive Strength Test Results}

The following table shows the results of the compressive strengths for the mortarless interlocking hollow blocks using the different shapes and cement to sand ratios.

Table 2: Compressive strength of mortarless hollow block(1:7 ratio)

\begin{tabular}{|c|c|c|c|c|}
\hline $\begin{array}{c}\text { Design } \\
\text { Sample A }\end{array}$ & $\begin{array}{c}\text { Specimen } \\
\text { Number } \\
(\mathbf{1 :} \text { 7) }\end{array}$ & $\begin{array}{c}\text { Compressive } \\
\text { Strength } \\
\text { (MPa) }\end{array}$ & $\begin{array}{c}\text { ASTM } \\
\text { Strength } \\
\text { Requirement } \\
\text { (MPa) }\end{array}$ & $\begin{array}{c}\text { PTSS } \\
\text { Requirement } \\
\text { (MPa) }\end{array}$ \\
\hline \multirow{3}{*}{$\begin{array}{c}\text { Corner } \\
\text { Block }\end{array}$} & $\mathrm{A} 1$ & 6.98 & 3.45 & 2.41 \\
\cline { 2 - 5 } & $\mathrm{A} 2$ & 8.15 & 3.45 & 2.41 \\
\cline { 2 - 5 } & $\mathrm{A} 3$ & 7.06 & 3.45 & 2.41 \\
\cline { 2 - 5 } & Average & $\mathbf{7 . 4}$ & $\mathbf{3 . 4 5}$ & $\mathbf{2 . 4 1}$ \\
\hline \multirow{3}{*}{$\begin{array}{c}\text { Straight } \\
\text { Block }\end{array}$} & $\mathrm{A} 1$ & 9.86 & 3.45 & 2.41 \\
\cline { 2 - 5 } & $\mathrm{A} 2$ & 7.76 & 3.45 & 2.41 \\
\cline { 2 - 5 } & $\mathrm{A} 3$ & 9.49 & 3.45 & 2.41 \\
\cline { 2 - 5 } & Average & $\mathbf{9 . 0 4}$ & $\mathbf{3 . 4 5}$ & $\mathbf{2 . 4 1}$ \\
\hline \multirow{3}{*}{$\begin{array}{c}\text { L-shaped } \\
\text { Block }\end{array}$} & $\mathrm{A} 1$ & 9.2 & 3.45 & 2.41 \\
\cline { 2 - 5 } & $\mathrm{A} 2$ & 8.67 & 3.45 & 2.41 \\
\cline { 2 - 5 } & $\mathrm{A} 3$ & 8.39 & 3.45 & 2.41 \\
\cline { 2 - 5 } & Average & $\mathbf{8 . 7 5}$ & $\mathbf{3 . 4 5}$ & $\mathbf{2 . 4 1}$ \\
\hline
\end{tabular}

Table 2 shows the compressive strength result of the different blocks using 1:7 proportion. It is shown that all values are higher than the ASTM strength requirement for $\mathrm{CHB}$ which is $3.45 \mathrm{MPa}$ and the PTSS requirement which is $2.41 \mathrm{MPa}$.

Table 3: Compressive strength of mortarless hollow Block (1:8 ratio)

\begin{tabular}{|c|c|c|c|c|}
\hline $\begin{array}{c}\text { Design } \\
\text { Sample } \\
\text { B }\end{array}$ & $\begin{array}{c}\text { Specimen } \\
\text { Number } \\
(\mathbf{1 : 8})\end{array}$ & $\begin{array}{c}\text { Compressive } \\
\text { Strength } \\
\text { (MPa) }\end{array}$ & $\begin{array}{c}\text { ASTM } \\
\text { Strength } \\
\text { Requirement } \\
\text { (MPA) }\end{array}$ & $\begin{array}{c}\text { PTSS } \\
\text { Requirement } \\
\text { (MPa) }\end{array}$ \\
\hline \multirow{3}{*}{$\begin{array}{c}\text { Corner } \\
\text { Block }\end{array}$} & $\mathrm{B} 1$ & 5.09 & 3.45 & 2.41 \\
\cline { 2 - 5 } & $\mathrm{B} 2$ & 5.8 & 3.45 & 2.41 \\
\cline { 2 - 5 } & B3 & 4.74 & 3.45 & 2.41 \\
\cline { 2 - 5 } & Average & $\mathbf{5 . 2 1}$ & $\mathbf{3 . 4 5}$ & $\mathbf{2 . 4 1}$ \\
\hline \multirow{3}{*}{$\begin{array}{c}\text { Straight } \\
\text { Block }\end{array}$} & $\mathrm{B} 1$ & 8.61 & 3.45 & 2.41 \\
\cline { 2 - 5 } & $\mathrm{B} 2$ & 7.36 & 3.45 & 2.41 \\
\cline { 2 - 5 } & B3 & 8.82 & 3.45 & 2.41 \\
\hline \multirow{3}{*}{$\begin{array}{c}\text { Average } \\
\text { Block }\end{array}$} & $\mathrm{B} 1$ & $\mathbf{8 . 2 6}$ & $\mathbf{3 . 4 5}$ & $\mathbf{2 . 4 1}$ \\
\cline { 2 - 5 } & $\mathrm{B} 2$ & 8.19 & 3.45 & 2.41 \\
\cline { 2 - 5 } & $\mathrm{B} 3$ & 8.57 & 3.45 & 2.41 \\
\cline { 2 - 5 } & Average & $\mathbf{8 . 1 4}$ & $\mathbf{3 . 4 5}$ & 2.41 \\
\hline
\end{tabular}

Table 3 shows the compressive strength result of the different blocks using 1:8 proportion. It is shown that all values are higher than the ASTM strength requirement for $\mathrm{CHB}$ which is $3.45 \mathrm{MPa}$ and the PTSS requirement which is $2.41 \mathrm{MPa}$. 
Francia H. Tomenio et al., International Journal of Emerging Trends in Engineering Research, 8(7), July 2020, 3804- 3810

Table 4:Compressive strength of mortarless concrete hollow block (1:10 ratio)

\begin{tabular}{|c|c|c|c|c|}
\hline $\begin{array}{c}\text { Design } \\
\text { Sample } \\
\mathbf{C}\end{array}$ & $\begin{array}{c}\text { Specimen } \\
\text { Number } \\
(\mathbf{1 : 1 0})\end{array}$ & $\begin{array}{c}\text { Compressive } \\
\text { Strength } \\
\text { (MPa) }\end{array}$ & $\begin{array}{c}\text { ASTM } \\
\text { Strength } \\
\text { Requirement } \\
\text { (MPA) }\end{array}$ & $\begin{array}{c}\text { PTSS } \\
\text { Requirement } \\
\text { (MPa) }\end{array}$ \\
\hline \multirow{4}{*}{$\begin{array}{c}\text { Corner } \\
\text { Block }\end{array}$} & $\mathrm{C} 1$ & 6.04 & 3.45 & 2.41 \\
\cline { 2 - 5 } & $\mathrm{C} 2$ & 7.06 & 3.45 & 2.41 \\
\cline { 2 - 5 } & $\mathrm{C} 3$ & 7.67 & 3.45 & 2.41 \\
\cline { 2 - 5 } & Average & $\mathbf{6 . 9 2}$ & $\mathbf{3 . 4 5}$ & $\mathbf{2 . 4 1}$ \\
\hline \multirow{3}{*}{$\begin{array}{c}\text { Straight } \\
\text { Block }\end{array}$} & $\mathrm{C} 1$ & 4.07 & 3.45 & 2.41 \\
\cline { 2 - 5 } & $\mathrm{C} 2$ & 4.29 & 3.45 & 2.41 \\
\cline { 2 - 5 } & $\mathrm{C} 3$ & 3.78 & 3.45 & 2.41 \\
\cline { 2 - 5 } & Average & $\mathbf{4 . 0 5}$ & $\mathbf{3 . 4 5}$ & $\mathbf{2 . 4 1}$ \\
\hline \multirow{3}{*}{$\begin{array}{c}\text { L-shaped } \\
\text { Block }\end{array}$} & $\mathrm{C} 1$ & 4.45 & 3.45 & 2.41 \\
\cline { 2 - 5 } & $\mathrm{C} 2$ & 3.51 & 3.45 & 2.41 \\
\cline { 2 - 5 } & $\mathrm{C} 3$ & 4.46 & 3.45 & 2.41 \\
\cline { 2 - 5 } & Average & $\mathbf{4 . 1 4}$ & $\mathbf{3 . 4 5}$ & $\mathbf{2 . 4 1}$ \\
\hline
\end{tabular}

Table 4 shows the compressive strength result of the different blocks using 1:10 proportion. It is shown that all values are higher than the ASTM strength requirement for $\mathrm{CHB}$ which is $3.45 \mathrm{MPa}$ and the PTSS requirement which is $2.41 \mathrm{MPa}$.

\subsection{Difference Between the Compressive Strength of the Mortarless Concrete Hollow Block and the ASTM Standards and PTSS Requirements}

Table 5: Difference between the compressive strength of the mortarless interlocking hollow block and the ASTM standards

\begin{tabular}{|c|c|c|c|}
\hline Design & Ratio & $\begin{array}{c}\text { Computed } \\
\text { value t }\end{array}$ & $\begin{array}{c}\text { Tabular } \\
\text { value of } \mathbf{~}\end{array}$ \\
\hline \multirow{2}{*}{$\begin{array}{c}\text { Straight } \\
\text { Block }\end{array}$} & $1: 10$ & 8.64 & 2.92 \\
\cline { 2 - 4 } & $1: 8$ & 10.56 & 2.92 \\
\cline { 2 - 4 } & $1: 7$ & 4.05 & 2.92 \\
\hline \multirow{3}{*}{$\begin{array}{c}\text { Corner } \\
\text { Block }\end{array}$} & $1: 10$ & 10.47 & 2.92 \\
\cline { 2 - 4 } & $1: 8$ & 5.64 & 2.92 \\
\hline \multirow{3}{*}{$\begin{array}{c}\text { L-shaped } \\
\text { Block }\end{array}$} & $1: 7$ & 7.28 & 2.92 \\
\cline { 2 - 4 } & $1: 10$ & 22.31 & 2.92 \\
\hline Sing & $1: 7$ & 39.84 & 2.92 \\
\hline
\end{tabular}

Since $t_{c}>t_{t}$, Reject the Ho, Accept Ha. Therefore, there is a significant difference between the compressive strength of the Interlocking Mortarless Hollow Blocks. and the ASTM Standards for CHB.

Using t-test, the difference between the compressive strength of the mortarless interlocking hollow block and the ASTM Standards. The computed $t$ value higher than the tabular value of $\mathrm{t}$ which is 2.92, therefore the Null Hypothesis which says that there is no significant difference between the compressive strength of the MIHB and the ASTM standards. Further, it shows that the compressive strength of the MIHB is greater than the ASTM standards.
Table 6: Difference between the Compressive Strength of the Mortarless Interlocking Hollow Block and the PTSS standards for CHB

\begin{tabular}{|c|c|c|c|}
\hline Design & Ratio & $\begin{array}{c}\text { Computed } \\
\text { value } \mathbf{t}\end{array}$ & $\begin{array}{c}\text { Tabular } \\
\text { value of } \mathbf{t}\end{array}$ \\
\hline \multirow{2}{*}{$\begin{array}{c}\text { Straight } \\
\text { Block }\end{array}$} & $1: 10$ & 10.24 & 2.92 \\
\cline { 2 - 4 } & $1: 8$ & 12.84 & 2.92 \\
\cline { 2 - 4 } & $1: 7$ & 11.1 & 2.92 \\
\hline \multirow{3}{*}{$\begin{array}{c}\text { Corner } \\
\text { Block }\end{array}$} & $1: 10$ & 13.22 & 2.92 \\
\cline { 2 - 4 } & $1: 8$ & 8.98 & 2.92 \\
\hline \multirow{3}{*}{$\begin{array}{c}\text { L-shaped } \\
\text { Block }\end{array}$} & $1: 7$ & 9.45 & 2.92 \\
\cline { 2 - 4 } & $1: 10$ & 26.69 & 2.92 \\
\hline Sing & $1: 8$ & 48.8 & 2.92 \\
\hline
\end{tabular}

Since $t_{c}>t_{t}$, Reject the Ho, Accept Ha. Therefore, there is a significant difference between the compressive strength of the Interlocking Mortarless Hollow Blocks and the PTSS Standards for CHB

Using a t-test, the difference between the compressive strength of the mortarless interlocking hollow block and the ASTM Standards. The computed $t$ value higher than the tabular value of $t$ which is 2.92, therefore the Null Hypothesis which says that there is no significant difference between the compressive strength of the MIHB and the PTSS standards. Further, it shows that the compressive strength of the MIHB is greater than the PTSS standards.

\subsection{Advantages of the Mortarless Interlocking Concrete Hollow Blocks in Terms of Cost}

The cost of the mortarless interlocking hollow blocks was determined. Table 7 shows the cost per piece using varied shapes and ratios. The cost of the mortarless interlocking hollow blocks was determined. For the straight block, corner block, and L-shaped block the most expensive is the ratio of $1: 7,(\mathrm{P} 12.13)$ while the cheapest is the one with a ratio of $1: 10$ (P9.65). For the corner block, the most expensive is the one with a ratio of 1:7 (P3.94) while the cheapest is with a ratio of 1:10 (P 3.60). For the L-shaped block, the most expensive is the one with a ratio of 1:7 (P16.35), while the cheapest is with a ratio of 1:10 (P13.80). Commonly used CHB costs about P10.00 per piece.

Table 7: The unit cost of the mortarless interlocking hollow blocks

\begin{tabular}{|c|c|c|}
\hline Design & Ratio & Cost (Pesos) \\
\hline \multirow{2}{*}{$\begin{array}{c}\text { Straight } \\
\text { Block }\end{array}$} & $1: 10$ & 9.65 \\
\cline { 2 - 3 } & $1: 8$ & 10.75 \\
\cline { 2 - 3 } & $1: 7$ & 12.13 \\
\hline \multirow{3}{*}{ Corner Block } & $1: 10$ & 3.60 \\
\cline { 2 - 3 } & $1: 8$ & 3.67 \\
\cline { 2 - 3 } & $1: 7$ & 3.94 \\
\cline { 2 - 3 } L-shaped & $1: 10$ & 13.80 \\
\cline { 2 - 3 } Block & $1: 8$ & 15.57 \\
\cline { 2 - 3 } Commonly-Used CHB & 16.35 \\
\hline \multicolumn{2}{|l|}{ CHB } \\
\hline
\end{tabular}


3.5 Cost During Installation. The estimated cost using ordinary Concrete Hollow Blocks (CHB) per unit area is Php 507.80. This includes the amount for the $\mathrm{CHB}$, mortar, and labor cost. The cost per unit area using the straight interlocking blocks

Table 8: Cost for installation and plastering per square meter

\begin{tabular}{|c|c|c|}
\hline Design & Ratio & Cost \\
\hline \multirow{3}{*}{ Straight Block } & $1: 7$ & Php 485.87 \\
\cline { 2 - 3 } & $1: 8$ & PhP 488.56 \\
\cline { 2 - 3 } & $1: 10$ & Php 490.85 \\
\hline $\begin{array}{c}\text { Commonly Used } \\
\text { CHB }\end{array}$ & & PhP 533.00 \\
\hline
\end{tabular}

Table 8 shows the cost for plastering and installation of MICB as compared with the commonly used $\mathrm{CHB}$ for one (1) square meter area. The cost for installation and plastering of the commonly used $\mathrm{CHB}$ is higher than the cost for laying-out the mortarless interlocking hollow blocks.

\subsection{Lay-out of Interlocking Mortarless Concrete Hollow Blocks}

The following figures show the different layouts of the three shapes of mortarless interlocking hollow blocks. The Mortarless Interlocking Concrete Hollow Blocks ( MICHB ) are laid staggered and upside down applying only a small amount of mortar in between layers and no more mortar is required to fill in the hollow block cells.

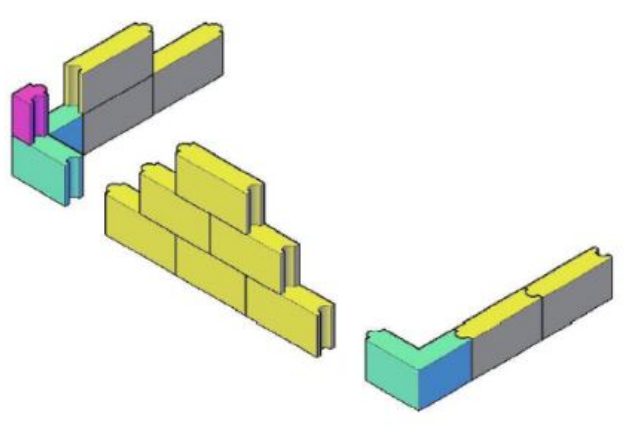

Figure 8: Lay-out of L-shaped blocks

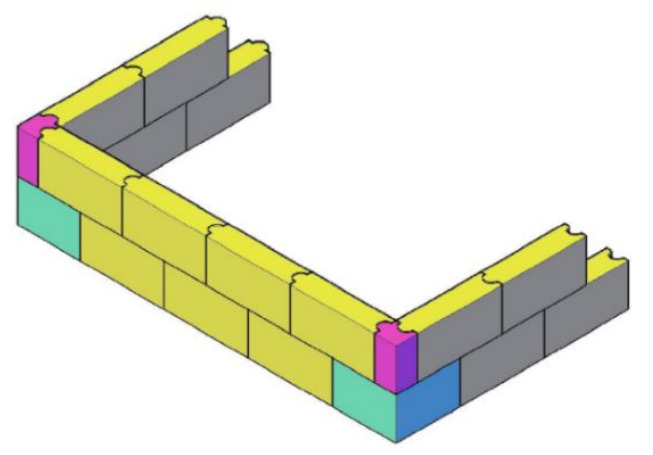

Figure 9: Lay-out of corner blocks

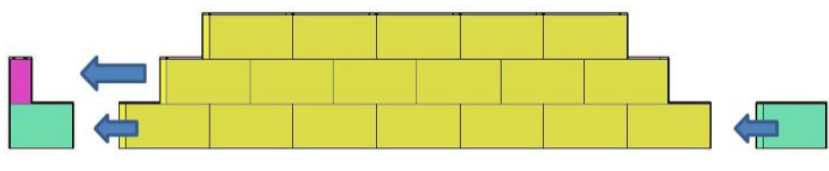

Figure 10: Lay-out of straight blocks

Figures 8,9 , and 10 show the installation of the mortarless interlocking hollow blocks for straight, L-shaped, and corner blocks.

\section{CONCLUSION}

The shapes of the mortarless interlocking hollow blocks are significant in the proper layout of walls and provide greater strength of the structure. From the compression strength test conducted, it was found out that the strength of the mortarless interlocking hollow blocks passed the ASTM and the PTSS standard, therefore its utilization is highly recommended. The cost per piece and the installation cost of the mortarless interlocking hollow blocks are lower as compared with the ordinary CHB.

The design of the molds could be improved by providing holes so that the reinforcing steel bars could be easily placed during installation. Additional indigenous materials may be added like rice hull ash and corn cob ash to improve the compressive strength of the interlocking blocks and to reduce its cost. Other designs may be proposed and studied to come up with the most efficient design of CHB. Design for load-bearing mortarless interlocking hollow blocks may also be considered.

\section{ACKNOWLEDGEMENT}

The researchers wish to thank the Center for Research and Development, Civil Engineering students, the Administration of Camarines Sur Polytechnic Colleges, and all who have been instrumental for the completion of this study.

\section{REFERENCES}

1. Q. Zhou, F. Wang, and F. Zhu, "Estimation of compressive strength of hollow concrete masonry prisms using artificial neural networks and adaptive neuro-fuzzy inference systems," Constr. Build. Mater., 2016.

https://doi.org/10.1016/j.conbuildmat.2016.08.064

2. D. Khalaf, Foud, Hendry, Arnold, Fairbairn, "Structural Journal," Am. Concr. Inst., vol. 91, no. 4, pp. 367-375, 1994.

3. M. F. Muda, S. W. Ahmad, F. Muftah, M. Syahrul, and H. Mohd, "International Journal of Emerging Trends in Engineering Research Mechanical Behaviour of Mortar Made with Washed Bottom Ash as Sand 
Replacement," vol. 7, no. 9, pp. 7-14, 2019.

4. S. Oyebisi, A. Ede, O. Ofuyatan, J. Oluwafemi, and I. Akinwumi, "Comparative study of corncob ash-based lateritic interlocking and sandcrete hollow blocks," Int. J. GEOMATE, vol. 15, no. 51, pp. 209-216, 2018. https://doi.org/10.21660/2018.51.45918

5. K. B. Anand and K. Ramamurthy, "Development and Evaluation of Hollow Concrete Interlocking Block Masonry System," Mason. Soc. J., vol. 23, no. 1, pp. 11-20, 2005.

6. N. A. Saffie, Nor, Mohd Nasir, Noor Azline, Ashour, Ashraf Fawzy, Bakar, "Behaviour of interlocking mortarless hollow block walls under in-plane loading," Aust. J. Struct. Eng., vol. 19, no. 9, pp. 87-95, 2018. https://doi.org/10.1080/13287982.2018.1433489

7. W. A. Thanoon, M. S. Jaafar, M. R. Abdul Kadir, A. A. Abang Ali, D. N. Trikha, and A. M. S. Najm, "Development of an innovative interlocking load bearing hollow block system in Malaysia," Constr. Build. Mater., vol. 18, no. 6, pp. 445-454, 2004.

8. M. A. Nasly and A. A. M. Yassin, "Sustainable Housing Using an Innovative Interlocking Block Building System," Int. J. Civ. Eng. Geo-Environmental, vol. 1, no. 1, pp. 1-9, 2010.

9. R. K.B., Anand, K., "Development and Performance Evaluation of Interlocking-Block Masonry," J. Archit. Eng., vol. 6, no. 2, p. 45, 2000.

10. M. S. Jaafar, , A. H. Alwathaf,, W. A. Thanoon, , J. Noorzaei, , and M. R. Abdulkadir, "Behaviour of interlocking mortarless block masonry," ICE Virtual Libr., vol. 159, no. 3, p. 111, 2006. https://doi.org/10.1680/coma.2006.159.3.111

11. Z. Zhao, Jun, Zhang, Jing Shu, Wang, Li, Liu, Le, Wang, "Development and Prospects of the Shapes of Concrete Hollow Block for Building Wall," Appl. Mech. Mater., vol. 777, pp. 201-211, 2015.

12. M. Ali, R. J. Gultom, and N. Chouw, "Capacity of innovative interlocking blocks under monotonic loading," Constr. Build. Mater., vol. 37, pp. 812-821, 2012. https://doi.org/10.1016/j.conbuildmat.2012.08.002

13. S. J. Ganesh and N. Lokeshwaran, "Experimental investigation on behavior of shear wall assembled with interlocking concrete block," Int. J. Civ. Eng. Technol., vol. 8, no. 3, pp. 111-117, 2017.

14. I, Open and A. Journal, "International Journal of Trend in Scientific Research and Development (IJTSRD ) HPLC : Principle and Maintenance with Application," pp. 1618-1626, 2018. https://doi.org/10.31142/ijtsrd17134 